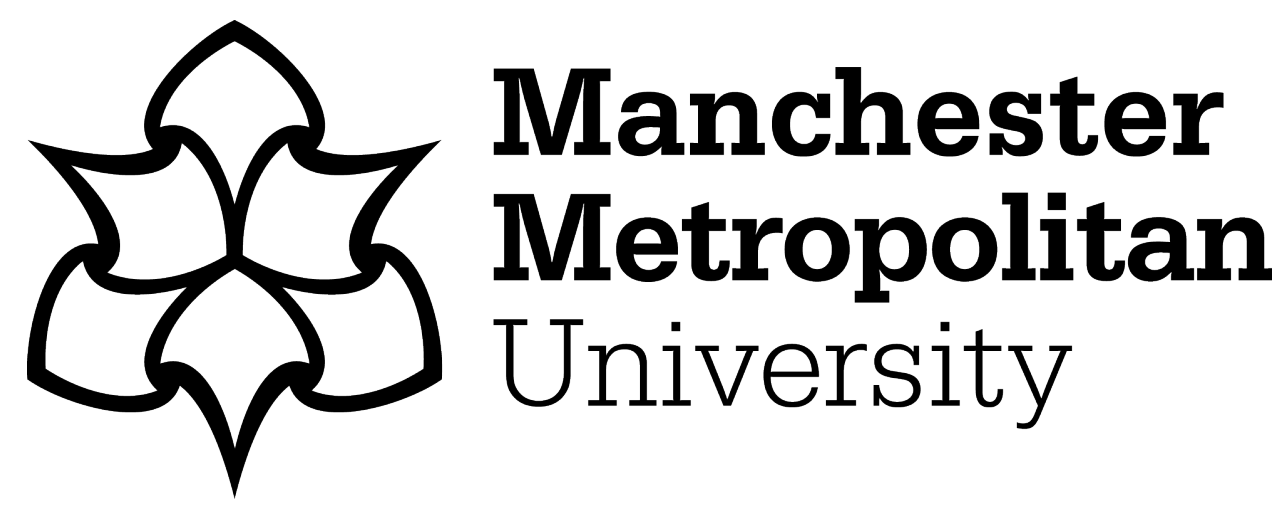

Duggan, James, Lindley, J and McNicol, S (2017) Near Future School: World building beyond a neoliberal present with participatory design fictions. Futures, 94. pp. 15-23. ISSN 0016-3287

Downloaded from: https://e-space.mmu.ac.uk/618413/

Version: Accepted Version

Publisher: Elsevier

DOI: https://doi.org/10.1016/j.futures.2017.04.001

Usage rights: Creative Commons: Attribution-Noncommercial-No Derivative Works 4.0

Please cite the published version 


\title{
Near Future School: World building beyond a neoliberal present with participatory design fictions
}

Duggan, J.R. (Manchester Metropolitan University), Lindley, J. (Lancaster University) and McNicol, S. (Manchester Metropolitan University)

\begin{abstract}
This article reports on one part of an on-going project, the Near Future School, which aims to translate and explore the potential of participatory design fiction practices for use with young people and those that work with them to explore near future scenarios of education that open up alternative and plural futures in the context of processes of foreclosure in a neoliberalising society. The focus here is to explore the practical and ethical issues of developing a speculative form of governance, using the philosophy of Benedict de Spinoza, as an act of imaginative world building through participatory design fictions. The research raises a series of questions and issues relating to understanding how design fiction's multiple inheritances, from fiction and design or art and design, need to be better understood and enacted within participatory design fiction processes.
\end{abstract}

Keywords: Participatory design fiction; Neoliberalism; Spinoza; World building

This article reports on one element of an on-going project in England, the Near Future School. The project aims to translate and explore the potential of participatory design fiction practices for pupils and teachers to explore near future scenarios that open up alternative and plural futures in the context of education amongst processes of deterministic foreclosure in a neoliberalising education system. Neoliberalisation is understood as the reconfiguration of education around performance-accountability targets and incentives, which foreclose the potential of school leaders and teachers to educate in ways that do not align with performative pressures. Participatory design fiction practices are explored as strategies to 
empower pupils and teachers to think beyond ways of organising education in the neoliberal present, imagining alternative forms of governance that maintain the possibility of resisting or negotiating the neoliberalisation of education.

The rationale for the research emerged from tensions between two strands of critical education futures research: The first strand is approaches to educational futures that seek to resist processes and pressures of foreclosure in the form of deterministic approaches to the future in education, whether managerialising and neoliberalising (Sandford, 2013) or anticipatory discourses and logics (Adams, Murphy and Clarke, 2009). From this work we understand the future as unknowable, open and mutable, locating the present as a site for creative and purposeful agency in articulating and moving towards plural and preferable futures (Miller, 2011; Facer, 2013). The second strand is the arguments and practices for supporting young people to vocalize their feelings toward future scenarios, reflect upon them, and be empowered to interpret the future, reflecting Sandford's call to develop 'practical methods for creating and sharing accounts of the future that are situated in the lived experience of those who will inhabit the future' (2013: 123).

While there are a range of research methods and practices that enable individual and collective visioning of potential futures for policy makers, practitioners and especially young people (e.g. Eckersley, 1999; Mallan and Greenaway, 2011; Istance and Theisens, 2013), the orientation for this research was to understand the participatory practices, spaces and lenses which might be appropriate for articulating and exploring educational futures with young people in recognition of neoliberalising 'foreclosure' of the future. The contribution is to explore practical and ethical issues related to developing speculative forms of governance, which are inspired by the philosophy of Benedict de Spinoza, as an act of imaginative world building through participatory design fictions.

The paper proceeds in 4 sections: One, an overview the partner school, the Northern Future Academy ${ }^{1}$ (NFA) was built to realise forms of teaching that were believed to be appropriate for the $21^{\text {st }}$ century. NFA is a well-suited partner for the project as it was engaged in a process of seeking to imagine and enact future forms of education. Two, design fiction is introduced and presented as a participatory futures practice. 
Three, the 'Near Future School' research project is introduced, in which we explored the use of participatory design fiction practices with pupils but found discussing problematic features of the school with the pupils to be practically and ethically challenging. Four, we reflect on the limits of participatory design fiction practice in schools within the context of neoliberal governance and consider future directions.

\section{Northern Future Academy}

The research developed over a series of visits to the Northern Future Academy (NFA), a mixed-ability mainstream school teaching pupils aged 11-16 years, in the north west of England. The academy is located in an area that can in part be described in terms of significant socio-economic disadvantage, one of the 100 most deprived of 32,844 lower-layer super output areas (LSOAs) in England (ONS, 2011). The school leaders and staff understood the challenges of addressing the multiple forms of disadvantage and working with the strengths of the pupils from the school's catchment area and they identified research as part of a wide-ranging strategy to improve teaching and learning in the school, both for the pupils and in relation to the performance-accountability regime schools are interpolated within. It was during these visits to explore improvement strategies that we became interested in the ways in which NFA was undergoing continual processes of adaptation to realise the academy's Building Schools for the Future vision of future-oriented teaching and learning.

Northern Future Academy was built as part of New Labour's - the United Kingdom's national government (1997-2010) - Building Schools for the Future (BSF) programme. BSF was a national, multi-billion pound initiative to build new schools according to innovative and transformative visions of $21^{\text {st }}$ century teaching and learning, developing schools that would improve pupil attainment whilst being adapted and adaptable to present and future pedagogical and technological changes, and preparing pupils for the $21^{\text {st }}$ Century (DfES, 2003; 4ps \& Partnerships for Schools, 2008).

The BSF programme as it manifested at the NFA was articulated around a vision for $21^{\text {st }}$ century education. The academy's approach was informed by the prominent discourse of $21^{\text {st }}$ century skills, a loose consensus of common skills (e.g. creativity, 
collaboration, information literacy and problem-solving) that workers and citizens of the $21^{\text {st }}$ Century ostensibly will need to thrive (Binkley et al. 2010; Voogt et al., 2013). At NFA this discourse was translated into pupils learning in large open spaces, independently and collaboratively engaging in project-based learning, in large, supported by one-to-one digital technology. Over a series of visits it became clear that the school leaders and teachers struggled to translate NFA's BSF vision into the anticipated forms of effective teaching and learning, within the particular context of the school. During the process, staff continuously experimented with various technologies for remediating the challenges of the open-plan building, such as fingerprint scanners to register pupils and speaker technologies to manage noise in class. We witnessed large, open learning spaces being retrofitted with soundproof walls to create traditional classroom-style teaching spaces, with similar reductions in pupils' agency in relation to independent and project-based learning.

This trajectory at NFA aligns with other attempts to build and sustain so-called $21^{\text {st }}$ century learning spaces, around technology and co-produced learning in England. School leaders reverse the spatial, pedagogical and technological innovation due to the pressures of the performance-accountability regime that require schools to maintain successful outcomes in pupil examinations, performance data and school inspection (Lewin and Solomon, 2013, 2016). Indeed, despite the ambitions to transform education the BSF programme was not unproblematic. It was beset by a series of contradictions, a limited evidence base and under-specified dimensions relating to, for example, design and pedagogy (Leiringer and Cardellino, 2011), and the early indication was that the programme produced mixed results that broadly failed to realise the anticipated transformation (Mahony, Hextall and Richardson, 2011; Mahoney and Hextall, 2013). Kraftl (2012) argues the transformative potential of the BSF programme was constrained by New Labour's neoliberalising social imaginary and governance - manifest in education via the performanceaccountability regime.

There was a putative contraction between BSF's aim to create educational spaces that were open and adaptable to emerging educational and technological developments, and the disciplinary power of the neoliberal performative regime 
within the English education system. Here we understand neoliberalism as the disenchantment of politics by economics (Davies, 2015), of the potential for competing or alternative values or rationalities in education. Thus neoliberalism in part functions through the paramerisation of life and the social according to economic rationalities. These structures and 'systems of institutional, subjective and relational power... parameterise the conditions of possibility' (Amsler, 2015 unpaged) and lead to 'the evisceration of a progressive imaginary' (Lingard, 2011: 335). These dynamics have played out since the 1980's in education in England through waves of managerialising and neoliberalising reforms; re-culturing and reconfiguring education through performative structures in the form of targets, inspections, league tables, performance management and robust accountable pressures (Thrupp and Willmot, 2003; Ball, 2003; Perryman 2006; Ranson 2008; Troman 2008). The reduction or abstraction, of education as it broadly or otherwise might be conceived to quantitative forms of performance-data such as standardised testing (Lingard, Martin and Rezai-Rashti, 2013) is a central feature of neoliberal governance in education (Ozga, 2009). Through the application of performative technologies, cultures and modes of regulation, performance data 'encapsulate or represent the worth, quality or value of an individual or organisation within a field of judgment' (Ball 2003: 216). Thus what it means to be a teacher, what outcomes are sought and how schools are constituted and organised are reconfigured and aligned with the incentives of the performative structures of the education system, specifically what 'works' in relation to primarily the targets of the performanceaccountability regime. It is this paramaterisation of education with performative pressures that we understand as sites and processes of futures foreclosure.

The intention here is not to evaluate whether or not NFA's original BSF vision was more effective or adaptable to future pedagogical or technological developments. Indeed, there is a case that the school's vision of large, open learning spaces and independent learning aligned with a prominent discourse of $21^{\text {st }}$ Century Skills might have been ill advised. The performative pressures therefore do not create perverse consequences - by, for example, constraining innovation in the school to provide an education that is putatively appropriate to the $21^{\text {st }}$ Century - but rather produce an 
intentional corrective to ineffective practices or school design as part of a 'selfimproving school system' (Hargreaves, 2010). Nevertheless, we were interested in the apparent trend for BSF schools to reverse local visions for future-oriented approaches to education and became increasingly interested in why particular decisions were made - why, for example, the open learning spaces were divided up and what technologies were introduced to address perceived problems - and the experiences and insight the pupils and teachers gained in participating in this process of continual adaptation to an envisioned future. We identified design fiction as an appropriate set of practices to explore these issues with the pupils and teachers by provisioning an alternative set of lenses and processes for opening discussions beyond neoliberalising forms of future foreclosure.

\section{Design fiction as participatory futures practice}

Design fictions combine elements of science fiction, science fact and design to frame the imaginative creation of diegetic prototypes - that is, prototypes that exist within story worlds (Bleecker, 2009). Design fiction is currently the most prominent field within a constellation of related speculative design practices such as critical design, counterfactual design, and design futures (Tonkinwise, 2015). The intention here, however, is not to review the history and development of design fiction as a field of practice (see for example Hales, 2013). An example design fiction project, developed by one of the authors, is Game of Drones which outlined a gamified system for using drones as a civic surveillance system. In the case of Game of Drones a fictional world was constructed through the articulation of possible future legislation, alongside designs for docking stations, signage, and screen views of the user interface (Lindley and Coulson, 2015). This project demonstrates the potential for using design fiction world building to not only consider the practicalities of alternate futures, but also to open space for discourse relating to the wider societal and ethical impacts of future alternatives. Our intention was to embark upon a participatory process working towards the same ends, but for young people to imagine, prototype and interrogate educational ideas and artefacts in education within the broader context of factors such as legislation, policy, curriculum and school design. 
Design fictions focus on the relationships between prototypical concepts and the fictional world that they would exist in. The materialization of ideas as prototypes, the processes, relationships and effects can be thought about in different ways - in relation to different understandings of what prototypes are (Jiménez, 2014). There is a case that ideas prototyped through fiction in a scenario or design fiction have different forms and purposes to the durable prototypes, as found in for example industrial design (Graham, 2013). Design fiction practitioners have demonstrated that it is possible, to create design fictions using a range of designed media, artifacts and experiences (e.g. text, images, props, found objects, exhibitions). Acknowledging this potential our focus is on learning from prototypes as 'socio-material configurations that embody existing and future practices in durable artifact's (Suchman, Trigg and Blomberg, 2002). We are interested in the potential 'performativity of prototypes', where performativity is not aligned with the disciplinary regime of power but rather as a site, practice and process of pre-figuring new educational arrangements at NFA and how in turn these might be explored, selected and implemented or resisted by staff and pupils. The aim of the design fiction world building, and the associated prototypes is to leverage their 'capacity to reify the future in present - not least in the coding of future practices... to durably translate and transform the interests of implicated actors.' (Wilkie, 2014: 479)

Design fiction proceeds by imagining and prototyping ideas or artifacts in fictional or story worlds. Story worlds can be understood as, 'if the story is the route-map and the narrative is the journey, then the story world is that territory of which the map is a necessarily incomplete facsimile' (Raven and Elahi, 2015: 51). For example, the design fiction scenario might focus on Northern Future Academy in the near future, or spatially it might be broader and include nearby cities or smaller and focus on a pupil's house. Yet design fiction scenarios are 'necessarily incomplete' visions into a more expansive and imagined story world, which lies beneath and beyond what is brought into view within the scenario. In seeking to understand the relationships between an educational prototype - in this research, a diegetic prototype of classroom organisation - we became interested in broader relationships between the prototype and the required or imagined, but absent features of, the story world 
such as, school curriculum, national educational policy, and data management systems. Thus, we began to expand the design fiction's usual frame of reference from a story world to include 'world making' (Markussen and Knutz, 2013) or 'world building' in providing a rich and detailed analysis of scenarios including 'creating "future histories" and laying out the political, technological, and historical development of peoples and worlds" (Wysocki 2012 quoted in Graham 2013).

Design fiction methods presented an opportunity to imagine and develop artifacts as prototypes and explore them in near future story worlds, and as part of an imaginative act of world building, in a participatory manner. We approached this act of world building in part through the specification of a theory of governance. If potential or alternative ways of organising education were foreclosed in the BSF programme and NFA in particular through neoliberal forms of performativity, our approach was to explore an alternative form of governance as an imaginative act of world building that might open up different ways of organising the school.

A theory of governance is constituted by joining an ontological understanding of human motivation within an assemblage of appropriate and coherent technologies of governance, rationalities, discourses and practices (e.g. Stoker, 2006; Stout, 2010). Thinking more broadly, a theory of governance provides a series of lenses through which we can explore the rules, rationalities, arrangements and relationships that constitute the processes of collective decision-making in education and schools (Stoker, 2004). To support this process of world building we explored a speculative theory of governance drawing on the philosophy of Benedict de Spinoza, in particular his work the Ethics (Spinoza, 1996). As a speculative form of governance this is an approach that is imagined and structures imaginative world building around considerations of how ontological commitments might relate to existing or entirely imagined ways of organising education, the ways that decisions might be made, how forms of accountability might be re-imagined. To develop this speculative governance we drew from Spinoza an affirmative and interdependent ontology of the individual or 'transindividual' and associated technologies of governance selected according to encouraging an increase in collective thinking 
powers (Balibar, 1998). The complexity of Spinoza's work meant this decision was not unproblematic, which we explain in more detail below.

To summarise, our approach was to use participatory design fiction scenarios to prototype educational arrangements in story worlds and develop these through imaginative processes of world building.

\section{Near Future School}

The Near Future School project sought to translate design fiction methods as a participatory research practice in education, in order to provide staff and students at NFA with a participatory process for imagining and prototyping near future visions of the school. After visiting NFA over a period of four years, we hosted an iterative series of 6 sessions to develop design fictions which prototyped and explored near future scenarios of the school. We worked with a group of 10 to 15 boys and girls, aged 13-14 years. The intention was not to explicitly or formally educate the pupils in ways of thinking about the future, but to enable pupils and teachers without any specialist knowledge in futures work to explore how things in their school might be different, preferable or the same (Slaughter, 1997).

The first five sessions took place at the NFA. The sessions began with a description of design fiction and the presentation of an example of design fiction output. Then we asked the students to imagine what their school might be like in 2018, in three years time, and suggested methods for presenting their visions: in week one, group discussions, in week two, short stories, and in week three comic strips. The fourth session involved the pupils playing with, then creating stories or comic strips, about being friends with a 'Nao robot' (an example of which was present at the school). $\mathrm{Nao}$ is a $58 \mathrm{~cm}$ tall interactive robot. The pupils reacted enthusiastically to $\mathrm{Nao}$ as it, for example, played music and danced in a range of different styles, from Elvis Presley's You Ain't Nothing But a Hound Dog to the Gangnam Style dance. We asked the pupils to consider, for example, what it would be like for their small friend to walk busy corridors or be bullied, to walk alongside Nao holding its hand to experience this, and write short fictional accounts about these encounters. 
The research took a significant turn in the fifth session. Again, the session began with an invocation to imagine what Northern Future Academy might be like in 2018, and the introduction of a creative method to support this exploration. Drawing on 'photovoice' methods (Wang, 2006), we suggested the pupils use iPad cameras to take photographs about their school and use these to discuss how they might like things to stay the same or change. Instead, four of the seven groups chose to write a short story of NFA in 2018.

Two girls wrote the scenario below which can be read in terms of prototyping space, in terms of the increasing allocation of space to classrooms and learning, rather than informal use or play:

Four years later, the building is bigger, the more children, the more overpopulated everywhere becomes, rooms need to be bigger, hardly any outdoor space. Fighting, scricking [sic], girls kicking off, the devil is possessing their minds. Depression, obsession, compulsive aggression. Everybody craves to be loved by someone. Break ups and make ups, it all swirls around us. We are puppets being controlled. Four years later, we are the lost generation. Four years later, everything has fallen. We are broken. And. We. Can't. Be. Fixed.

The next scenario, written by a boy and two girls, includes a number of prototypical concepts including fingerprint scanners (which were faulty), punishment fines, and frequently changing forms of certification:

I put my gloves on they kept my fingers clean since the goddamn finger print scanner is so faulty! Seriously! It only accepted 'perfectly' pristine fingers that had no water, crisps, mud or anything associated with it. I arrive at the school buildings, domes and bridges scattered around the shiny, clean campus. Litter anything and you'll get fined. Since I'm 16 and was doing my GCFE's (the new test the government regulated for this year), I had to go to the underground study and exam area for optimal learning.

During the session, we were unsure how to respond to the pupils' scenarios. This was, in part, because an anxiety had grown in us in response to the pupils' apparent 
despondency and hopelessness. Responding to this negative affect became even more problematic when, reflecting on the research on the BSF programme (e.g. Kraftl, 2012; Lewin and Solomon, 2013, 2016), we began to reinterpret these necessarily incomplete scenarios through a process of world building in terms of the NFA's responses to the pressures of neoliberalising performativity, reducing education to the parameters of performance-accountability regime.

One could, for example, understand the configuring of the space in the school, increasing the amount of space allocated to classrooms and learning, rather than for play, as a response to the performative pressures placed on schools by government to increase pupil academic achievement. More space allocated to teaching and learning might improve performance in examinations, although equally it may not. The attempt to interpret and build worlds around the scenarios emerging from our design fiction process was problematic for a number of reasons.

One, the term 'neoliberalism' is for some an over-used, under-specified and diverse concept applied to multiple phenomena across various geographical and temporal contexts (Rowlands and Rawolle, 2013; Brown, 2015). The presence of finger scanners in a busy school does not require neoliberalism as an explanation. Two, it was unlikely that the pupils knew what neoliberalism was and perhaps were simply taking an opportunity to complain to the teachers about things they did not like at NFA in the present. Indeed, NFA has installed temperamental finger scanners. Three, and most significant, we were confronted by the fraught ethical challenges of discussing neoliberalism - whatever it might be taken to mean - with the pupils. Neoliberalism is understood in part as discourses and practices of violence (Springer, 2011). In education, pupils may experience this violence through and in relation to engendered subjectivities around competitiveness and value, defined as academic success in class activities and examinations (Wilkins, 2012), and processes of sorting and stratifying pupils into winners or losers (i.e. academically successful or not).

To compound these issues, we noticed in the space we were working in, through a window to an adjacent office but in plain sight to the pupils, an A1-size card with passport photographs of all the pupils charting their academic position in relation to each other and required 'levels of progress' for academic achievement, from high 
and achieving to low and failing. Although relatively simple (i.e. paper, photographs and blu-tac), this 'performance matrix' was an analogue technology interpolated and related to the systems of data management and structures of performanceaccountability through which education is managed (Lynch, 2015). Performance matrices are not uncommon in English schools but are usually not visible to the pupils (e.g., located in the staffroom). We were interested what it meant to sit in class or indeed be asked to imagine an alternative form of education with other pupils while being in full view of one's 'low' or 'high' academic position, as displayed on the performance matrix. While the pupils had described various negative features of NFA, they had not mentioned the performance matrix, either it being a taken-forgranted part of the fabric of the school or an unutterable manifestation of the pressures both the pupils and the school endure. Perhaps, the lack of reference to the matrix by the pupils was a reflection of how entrenched their collective status quo is, and hence an indicator of difficulty in meaningfully imagining alternatives.

After the session, reflecting on how to proceed with the research we decided to understand the performance matrix as an artefact we could prototype in a design fiction world, a world that would take cues from Spinoza. We attempted to reimagine the matrix within an imaginary world, one in which the matrix and the school was not organised according to the disciplinary power of neoliberal governance and performative structures but rather an alternative and affirmative form of governance. Through this fictional re-imagining we hoped to create sufficient distance for the pupils to talk about both the performance matrix, and in a more general sense about how education and academic performance might be understood.

In order to do this, we drew on the philosophy of Benedict de Spinoza, especially his Ethics (Spinoza, 1996). The decision to use Spinoza was not unproblematic. The Ethics, for example, was published in 1677 and written in Latin according to a geometric method that presents definitions, axioms, propositions and scholia to build an intricate philosophical system in 5 books. The Ethics is dense and open to multiple interpretations. Due to the complexity and unfamiliarity of the ideas, the Ethics requires careful exegesis and explanation. There is not space here to 
adequately outline Spinoza's work (cf. Deleuze 1998, 1990), and we therefore focus on the challenge of how to productively explore this arcane and difficult philosophy with young people to imagine and interrogate preferable forms of contextualised and located education. Spinoza was selected as his work offers an alternative ontological understanding of human motivation for a 'speculative' or imagined form of governance that helped to explicate why educational artefacts or arrangements were included in the design fiction scenario, and the relationships to other required or anticipated artefacts or institutions within the education system in this imagined world.

An approach to specifying an alternative form of governance is to establish an ontological understanding of human motivation and relate this to an assemblage of appropriate and coherent technologies of governance, rationalities, discourses and practices (Stoker, 2006; Stout, 2010). Spinoza understands human motivation through the idea of the conatus, or the drive by which 'each thing, as far as it can by its own power, [and] strives to persevere in its being' (Spinoza, 1996, IIIP6). Spinoza eschewed Thomas Hobbes's foundation myth of society in which self-interested, atomised individuals became subject to a sovereign to avoid a war of 'all against all' (Montag, 1999). Instead, he outlined a relational and affirmative ontology that has been described as 'transindividualism' (Balibar, 1997). Spinoza, therefore, engages with the immanent reality of relational and interdependent collective life,

... to man, then, there is nothing more useful than man. Man, I say, can wish for nothing more helpful to the preservation of his being than that all should so agree... that all should strive together, as far as they can, to preserve their being; and that all, together, should seek for themselves the common advantage of all. (Spinoza, 1996: IVP18s)

The second step in outlining a theory of governance which adopts a Spinozist approach is to identify and assemble appropriate technologies, rationalities and approaches to decision making. For the task, we refer to Etienne Balibar whose reading of Spinoza defines the relationship between the rational and affective in collective life, describing how people can thrive in conditions of sociability (Balibar, 1998). Joy is fundamental in Spinoza to the processes of collective empowerment 
and emancipation, or potentia. The experience of joy is not hedonic but rather the affect associated with our increase in power to think and act, where sadness is our experience of our powers diminished (Hardt, 2015). Thus, we began to articulate a speculative governance in terms of the ontological understanding of human motivation as conatus and the movement towards joy, and associating this with an assemblage of governance, rationalities and discourses so that as many as possible, think as much as possible.

\section{Translating Spinoza into design futures practice for education}

It is not a straightforward task to incorporate this Spinozist perspective into design fiction which addresses education governance. Both the multiple interpretations of his work and, despite a few scattered references the lack of direct attention to a pedagogical vision (Lloyd, 1998), present significant challenges. Indeed, in general 'Spinoza's suggestions for the collective cultivation of reason and joyful affects in light of our radical finitude remain underdeveloped... he is not very clear about the precise practices, institutions, or environments that fortify thinking' (Sharp, 2007: 750). We leverage this interpretive flexibility of Spinoza and import the same flexibility to the production of our design fictions, or, put differently, we approached the task with a good deal of poetic licence.

The scenario below was written by the research team as a strategy to reinterpret the performance matrix, as a stimulus for discussion with the pupils while distancing the artefact from the pupils' experience of their school. The scenario seeks to prototype an alternative an alternative configuration of the performance matrix within a fictional world which includes a form of Spinozist pedagogy:

I was teaching 9B Ecosophy. It was all going according to my lesson plan. The pupils conceived their visions last week, now we're working on sharing them with their classmates, forming common notions, and increasing their collective thinking power. All of them raising their faces to the scanners to ensure the increase in power registers. The nodes on the matrix glowing green, growing closer. Then that Bento kid, shouts out from the back, "How do the scanners measure intuitive knowledge? If it's just affects, isn't that the source of error?" I laughed out loud! On the 
board, mine and Bento's nodes glowed green and moved together. The whole class's nodes went red and dropped away. I panicked! Thank God the data is wiped.

The performance matrix prototyped in the scenario represents readings of biosensors that monitor, track and represent the pupil's affective responses and relationships as they experiencing joy or sadness, an increase or decrease their collective thinking powers along with their classmates. Indeed, although rudimentary, facial recognition and biosensor systems have been developed and so are potentially available for use in English schools (Davies, 2015). Bento's, the pupil, interruption identifies that readings of affective responses can only be imperfect approximations or proxies for cognitive processes and learning, and in Spinoza's vision, developing intuitive understanding of the world. We included the disruptive pupil Bento, one of Spinoza's given names, to introduce the passionate and disruptive element of thinking and education into the design futures scenario. Indeed, thinking of joy as the foundation of an education might sound sublime and harmonious. Massumi (2015: 44-45) cautions, however, that in the Spinozist sense, "joy as affirmation, an assuming by the body of its potentials, its assuming of a posture that intensifies its powers of existence" is potentially disruptive, dangerous and painful when, for example, "words that burst apart and lose their conventional meaning, becoming like a scream of possibility, a babble of becoming, the body bursting out through an opening in expression."

The practice of producing the design fiction, thinking with Spinoza and developing a Spinozist form of governance through world building, was productive for the research team. Interpreting and translating an arcane and dense philosophy into specified and imagined learning contexts presented an opportunity to articulate and explore alternative relationships, rationalities and values between pupil, teacher and the performance matrix.

As a form of participatory research practice, however, we would have needed to present the performance matrix scenario to the pupils to read and discuss it with them but this is something we did not feel able to do. There is much written into the scenario that is not obvious, which reflects the challenge and purpose of design 
fiction world building. We understood the purpose of the design fiction scenario not to depict the 'best' or 'worst' of all possible worlds, or indeed to present a particular didactic point, but rather to invoke one of many possible futures in order to provoke questions and discussion with the pupils. For example: in what world would Ecosophy exist, and what role would it play? What is 'intuitive' knowledge? How do affects relate to the 'source of error'? What is the error? What data is collected and wiped? Why and how does this happen? Why a performance matrix? It may have been that the questions above would resonate with the pupils. However, after much deliberation, we felt that we could not discuss the matrix with the pupils at NFA.

The research increasingly focused on exploring and discussing with the pupils the performative structures. The performance matrix, in either its actual or reinterpreted forms, was a discrete representation of the performative pressures and structures in the school yet when confronted with making the performance matrix visible and audible in discussions with the pupils we became increasingly uncomfortable. How does, for example, the presence of the performance matrix in Northern Future Academy relate to the 'struggle against unjustifiable judgment and authority and for dignified relationality' (Skeggs and Loveday, 2012: 472)? Whether the performance matrix was justifiable or not is an open question. There are in the United Kingdom alone approximately 8.2 million pupils are educated in 24,372 schools (DfE, 2014) suggesting that forms of rationality, mediation, institutional design and co-ordination might be required in an education system (Barnett, 2010). The speculative governance we sought to develop was oriented to opening up ways of organising education founded upon the struggle 'for dignified relationality' yet this prospective world was imagined in a neoliberalising present.

There are considerable ethical dilemmas in teaching or researching futures with pupils (Bateman, 2015), especially including pupils in discussions upon neoliberalising processes and practices if these are understood as forms of violence pupils' experience (e.g., Springer, 2011). There are, however, examples of ethical participatory research practice that explores racial, social and structural forms of violence and exclusion with young people (e.g. Cahill, Rios-Moore and Threatts, 2008). The pupils' perceptions and affects of the performance matrix, the 
intersection of the impersonal forces of neoliberalising performative education in an artefact, was the productive empirical territory we sought to explore. However, as the research progressed, focusing on the performance matrix, the agreement with the teachers to conduct research had changed and significantly we did not have a credible process for ensuring the participatory process informed and fed into school decision-making structures. At risk of false consultation with the pupils, we decided to terminate the research in the school and re-locate and re-focus the project. Thus, in the final section we consider how might we understand the potential contribution of participatory design fiction practice.

\section{Re-considering the potential of participatory design fictions}

The aim of the Near Future School was to use participatory design fiction practices prototyping new ways of organising and doing education in fictional worlds - to resist foreclosure of the future at NFA. A significant challenge for the research was arriving at an impasse where we felt that practically and ethically we could not communicate with the pupils about the potentially problematic artefacts and affects we identified. As we now go on to develop the Near Future School project we seek to clarify the potential contribution of participatory design fiction practices in relation to three emerging concerns:

One, understand how the process of communicating and supporting the production of participatory design fiction practices might engender particular lenses, enable or prevent ways of thinking, affects and orientations towards plural futures. Encountering the pupils' negative affect, the apparent sense of hopelessness communicated in the scenarios was challenging. There is an established debate in participatory futures research as to what young people's imagined futures relate: to hoped for or feared futures. There are more persuasive orientations that seek to progress beyond binaries of hope or hopelessness (e.g., Miller, 2011). It is therefore helpful to think through how the previous iteration of the NFS was structured, and how we might provide pupils with tools, resources and processes to think beyond or challenge the neoliberalising present.

In the first iteration of the NFS we adopted an open and relatively unstructured approach, with no chaperoning towards a predefined process or invocation of, for 
example, design thinking methods. To understand the potential consequences of this requires unpacking some of the multiple inheritances that constitute what design fiction is made up of. For example, design fiction has creative, future-making, human-centred, speculative, critical, materialising, and evaluative attributes (Tonkinwise, 2015), which are inherited from the design discipline. From literary fiction the practice obtains interpretive and creative lenses of character, narrative arc and plot, tension and conflict, affect and emotion, as well as verisimilitude and fantasy (Blythe, 2016). Greater attention is required to understand from where pupils drew ideas, genres and templates for producing their design fiction scenarios. For example, was the hopelessness communicated in the scenarios a reflection of broader cultural tropes of dystopia or apocalypse in contemporary films, fiction and the media? How might a greater emphasis on design thinking and practices support pupils in specifying prototypes and interrogating them in near future scenarios? What lenses, discourses and genres from design might prove useful in participatory processes that seek to think beyond the neoliberalising present?

Two, how might participatory design fiction practice open up alternative possible futures for the pupils at NFA given that the pupils and the school remained interpolated within the same performative education structures we were seeking to unsettle or think beyond. Whether design fictions are meant to make a practical contribution to re-organising a school might depend if we understand design fiction as a design or art practice. Bardzell and Bardzell (2013) argue that the difference between design fiction and art is not ontological but rather relating to the constitutive discourses and practices. Understood as affirmative design, we could explore how features of the scenario facilitate 'moving from existing to preferred situations' (Simon 1969: 130). Alternatively, the practices and criteria for making and judging art, emphasising ambivalence and asserted without pre-fixed criteria of value, provide a productive set of lenses for producing and interpreting design fiction scenarios but also in relating near future scenarios to forms of experimentation and creativity (Sommer, 2014).

Therefore, instead of engaging design fiction in terms of the use and utility of designing solutions to problems, participatory design fiction practices might better 
be thought of as convening a 'discursive space' (Lindley, 2015) which plays an influencing role in a cycle that incorporates representations of the past and future, but may only be interpreted in the present (Gonzattoa, et al., 2013). These spaces might invite pupils into an expanded debate on new educational artefacts or arrangements that incorporate questioning and opening discussion around the values and criteria which inform the assessments by which decisions are made. Learning from experiences of 'pupil voice' practices in education, which open spaces and opportunities for pupils to give voice to their concerns and be heard by staff; these spaces are not unproblematic and voice is performed and enacted within and in relation to existing power structures and disciplinary technologies in education (Bragg and Manchester, 2012). Nevertheless, there are indications the pupils used the design fiction scenarios to communicate dissatisfaction with the school, for example, with the fingerprint scanners. Questions do persist, however. For example, how near-future discursive spaces and participatory design fictions could enable difficult conversations between pupils, teachers and researchers, whether locating requests for change within stories or story worlds might in fact make pupil's requests for change easier for staff to ignore.

Three, there is a case that developing speculative theories of governance could structure and document the articulation, contextualisation and exploration of new values and processes for making collective decisions. But, how might participatory processes including pupils be configured? Articulating a theory of governance from academic texts was useful for the research team but it remains an open question whether this is a practical method for developing scenarios with pupils or whether these scenarios might be used as stimuli or provocations for discussions with pupils and teachers. Using a participatory approach, we open an alternative way to support the pupils design an educational artefacts and arrangements, as well as prototyping them in fictional worlds. It is in these discussions, thinking through how relationships and decisions might be made and understood that emergent forms of governance might develop. As yet, it is unclear whether these conversations about problematic features of neoliberalising education can ethically and practically take place within mainstream education settings, such as NFA. It is possible that the processes 
necessary to think beyond neoliberalising education must begin beyond it in alternative educational spaces and settings, or, perhaps, beyond education itself.

\section{Conclusion}

The aim of Near Future School project was to translate and develop participatory design fiction practices to support pupils and teachers in thinking through new ways of governing education beyond a neoliberalising present. That is a present which tends towards foreclosing the plurality of the future. Participatory design fictions and the orientation to near future was intended to provide a discursive space in which we might imagine and explore education scenarios with pupils at Northern Future Academy. Developing a speculative form of governance as an imaginative world building act was productive for the research team in seeking to imagine and interrogate educational scenarios beyond a neoliberal present. However, we reached practical and ethical impasse in feeling incapable of discussing potentially problematic features of the scenarios and Northern Future Academy with the pupils themselves. Further work is required to understand how the multiple disciplinary inheritances of design fiction practice might relate to the purposes, processes and outputs of participatory design fiction scenarios. In particular whether a greater emphasis in the research on supporting the pupils to draw from participatory design practices might provide pupils with additional resources to imagine and interrogate near future scenarios beyond affects of hopelessness and practices and processes of a neoliberalising present.

\section{References}

4ps and Partnerships for Schools (2008). An introduction to Building Schools for the Future. London, Department for Children, Schools and Families.

Adams, V., Murphy, M. and Clarke, A.E. (2009). Anticipation: Technoscience, life, affect, temporality, Subjectivity, 28, 246-265

Balibar, E. (1997). Spinoza: From Individuality to Transindividuality. Delft: Eburon.

Balibar, E. (1998). Spinoza \& Politics. London; New York: Verso.

Ball, S. J. (2003). The teacher's soul and the terrors of performativity. Journal of 
Education Policy, 18(2), 215-228.

Bardzell, J., and Bardzell, S. (2013). What is "critical" about critical design? CHI 2013: Changing Perspectives, Paris, France.

Barnett, C. (2010). Publics and Markets: What's wrong with Neoliberalism? In and J. P. J. I. Susan Smith, Sallie Marston, Rachel Pain (Ed.), The Handbook of Social Geography. London; New York: Sage.

Bateman, D. (2015). Ethical dilemmas: Teaching futures in schools. Futures. 71, 122131.

Bleecker, J. (2009). Design Fiction: A Short Essay on Design, Science, Fact and Fiction. Near Future Laboratory, 49. Available at:

http://www.nearfuturelaboratory.com/2009/03/17/design-fiction-a-short- essay-ondesign-science-fact-and-fiction/

Blythe, M. (2016) The Co-ordinates of Design Fiction: Extrapolation, Irony, Ambiguity and Magic, Proceedings of the 19th International Conference on Supporting Group Work, Sanibel Island, Florida, USA - November $13^{\text {th }}-16^{\text {th }}$. Available at: http://dl.acm.org/citation.cfm?doid=2957276.2957299

Brown, W. (2015). Undoing the Demos: Neoliberalism's Stealth Revolution. New York: Zone Books.

Cahill, C., Rios-Moore, I. and Threatts, T. (2008). 'Different Eyes/Open Eyes: Community-Based Participatory Action Research', in J. Cammarota and M. Fine (eds.) Revolutionizing Education: Youth Participatory Action Research in Motion, pp. 89-124.

Davies, J.S. (2011). Challenging governance theory: From networks to hegemony. Bristol: Policy Press.

Davies, W. (2015). The Happiness Industry: How the Government and Big Business Sold Us Well-Being. London: Verso. 
Deleuze, G. (1988). Spinoza: Practical Philosophy, trans. R. Hurley. San Francisco: City Lights Books.

Deleuze, G. (1990) Expressionism in Philosophy: Spinoza, trans. M. Joughin. New York: Zone Books.

DfE. (2014). Number of schools, teachers and students in England, FOI Request. Available at: https://www.gov.uk/government/publications/number-of-schoolsteachers-and-students-in-england

DfES. (2003). Building Schools for the Future: Consultation on a new approach to capital investment. London.

Eckersley, R. (1999). Dreams and expectations: young people's expected and preferred futures and their significance for education, Futures, 31, 73-90.

Facer, K. (2011). Learning futures: Education technology and social change. London \& New York: Routledge.

Facer, K. (2013) The problem of the future and the possibilities of the present in education research, International Journal of Educational Research, 6, pp. 135-143.

Gonzattoa, R.F, van Amstela F.M.C., Merkleb, L.K., Hartmann, T. (2013) The ideology of the future in design fictions, Digital Creativity, 24(1), pp. 1-10,

Graham, G. (2013) Exploring imaginative futures writing through the fictional prototype 'crime-sourcing', Futures, 50, pp. 94-100

Hales, D. (2013) Design fictions an introduction and provisional taxonomy, Digital Creativity, 24(1), 1-10.

Hardt, M. (2015). The Power to be Affected. International Journal of Political Cultural Sociology, 28, 215-222

Hargreaves, D.H. (2010) Creating a self-improving school system. Nottingham: National College of School Leadership.

Lindley, J. (2015). A pragmatics framework for design fiction, paper presented at $11^{\text {th }}$ European Academy of Design Conference, Paris, April 22-24, 2015 
Lindley, J. and Coulton, P. (2015). Game of Drones. In CHI PLAY '15 Proceedings of the 2015 Annual Symposium on Computer-Human Interaction in Play, pp. 613-618, New York: ACM. DOI: $10.1145 / 2793107.2810300$

Mahony, P., Hextall, I., and Richardson, M. (2011). Building Schools for the Future': reflections on a new social architecture. Journal of Education Policy, 26(3), 341-360.

Mahony, P. and Hextall, I. (2013). Building Schools for the Future': 'transformation' for social justice or expensive blunder? British Educational Research Journal, 39(5), 853-871.

Istance, D. and Theisens, H. (2013). Thinking about the future: Insights from an international project, International Journal of Educational Research, 61, 111-115.

Corsín, J.A. (2014) Introduction: The prototype: more than many and less than one, Journal of Cultural Economy, 7(4), 381-398.

Kraftl, P. (2012). Utopian Promise or Burdensome Responsibility? A Critical Analysis of the UK Government's Building Schools for the Future Policy. Antipode, 44(3), 847870.

Leiringer, R. and Cardellino, P. (2011) Schools for the twenty-first century: school design and educational transformation. British Educational Research Journal, 37(6), 915-934.

Lewin, C., Solomon, Y. (2013). Silencing the School Bell? Reflecting on One School's Transformational Journey. International Review of Qualitative Research, 6(3), 376394.

Lingard, B., Martino, W. and Rezai-Rashti, G. (2013). Testing regimes, accountabilities and education policy: commensurate global and national developments, Journal of Education Policy, 28(5), 539-556.

Lynch, T.L., (2015). The Hidden Role of Software in Education: Policy to Practice. London: Routledge.

Mallan, K. and Greenaway, R. (2011). School, images of the futures and social processes in classrooms, Futures, 43, 374-386. 
Markussen, T., \& Knutz, E. (2013). The Poetics of Design Fiction. Proceedings of the 6th International Conference on Designing Pleasurable Products and Interfaces DPPI'13, 231-240.

Massumi, B. (2015). Politics of Affect. Cambridge; Malden, MA: Polity Press.

Miller, R. (2011). Being without existing: The futures community at a turning point? A comment on Jay Ogilvy's 'facing the fold'. Foresight, 13(4), 24-34.

Montag, W. (1999). Bodies, Masses, Power: Spinoza and His Contemporaries. London; New York: Verso.

ONS (2011) 2011 Census, Available at: https://www.ons.gov.uk/census/2011census

Ozga, J. (2009). Governing Education through Data in England: From Regulation to Self- Evaluation. Journal of Education Policy. 24(2), 149-162.

Raven, P. G., \& Elahi, S. (2015). The New Narrative: Applying narratology to the shaping of futures outputs. Futures, 74, 49-61.

Rowlands, J., \& Rawolle, S. (2013). Neoliberalism is not a theory of everything: a Bourdieuian analysis of illusio in educational research. Critical Studies in Education, 54(3), 260-272.

Sandford, R, (2013). Located futures: Recognising place and belonging in narratives of the future. International Journal of Educational Research, 61, 116-125

Sharp, H. (2007). The Force of Ideas in Spinoza, Political Theory, 35(6), 732-755.

Simon, H.A. (1969). The Sciences of the Artificial. Cambridge, Mass: MIT Press.

Skeggs, B. and Loveday, V. (2012). Struggles for value: value practices, injustice, judgment, affect and the idea of class, The British Journal of Sociology, 63(3), 472490.

Slaughter, R.A. (1997). Near-Future Landscapes as a Futures Tool. Futures, 29(7), 617-632, 
Solomon, Y. and Lewin, C. (2016). Measuring 'progress' : performativity as both driver and constraint in school innovation. Journal of Education Policy, 31(2), 226238.

Sommer, D. (2014). The Work of Art in the World: Civic Agency and Public Humanities, Durham, NC: Duke University Press.

Spinoza, B. (1996). Ethics. London; New York: Penguin Books.

Springer, S. (2011). Violence sits in places? Cultural practice, neoliberal rationalism, and virulent imaginative geographies, Political Geography, 30, 90-98.

Srnicek, N., Williams, A. (2016). Inventing the Future: Postcapitalism and a World Without Work. London: Verso.

Stoker, G. (2006). Public value management: a new narrative for networked governance? The American Review of Public Administration, 36(41), 41-57.

Stout, M. (2010). Back to the Future: Toward a Political Economy of Love and Abundance. Administration \& Society, 42(1), 3-37.

Suchman, L., Trigg, R. and Blomberg, J. (2002). Working artefacts: ethnomethods of the prototype, British Journal of Sociology, 53(2), 163-179.

Thrupp, M. and Wilmott, R. (2003). Education management in managerialist times: beyond the textual apologists, Maidenhead: Open University Press.

Tonkinwise, C. (2015). Being Dogmatic about Defining Speculative Critical Design Future Fiction. Just Design.

Wang, C. (1999). Photovoice: A participatory action research strat- egy applied to women's health. Journal of Women's Health, 8(2), 185-192.

Wilkie, A. (2014). Prototyping as Event: Designing the Future of Obesity. Journal of Cultural Economy, 7(4), 476-492.

Wilkins, A. (2012). Push and pull in the classroom: competition, gender and the neoliberal subject. Gender and Education, 24(7), 765-781. 
Wysocki, E. (2012) The Great Heinlein Mystery: Science Fiction, Innovation and Naval Technology, Createspace, Seattle. In G. Graham, Exploring imaginative futures writing through the fictional prototype 'crime-sourcing', Futures, 50, pp. 94-100. 